\title{
Human Dirofilariosis: The report of subcutaneous Dirofilaria repens infection in the Slovak Republic
}

\author{
E. NOVÁKOVÁ ${ }^{1}$, J. KINČEKOVÁ ${ }^{2}$, K. ADAMICOVÁ ${ }^{3}$, J. KOMPANÍKOVÁ ${ }^{1}$, V. ŠVIHROVÁ ${ }^{4}$, K. ŠIMEKOVÁ $^{5}$, \\ J. KRAUSE ${ }^{6}$, J. PAVLINOVÁ ${ }^{2}$, E. DVOROŽŇÁKOVÁ ${ }^{2}$
}

\begin{abstract}
${ }^{1}$ Institute of Microbiology and Immunology, Jessenius Faculty of Medicine Comenius University in Martin;
${ }^{2}$ Parasitological Institute, Slovak Academy of Sciences, Hlinkova 3, 04001 Košice, Slovak Republic, E-mail:dr.kincek@gmail.com; ${ }^{3}$ Institute of Pathological Anatomy, Jessenius Faculty of Medicine Comenius University in Martin; ${ }^{4}$ Institute of Public Health, Jessenius Faculty of Medicine Comenius University in Martin;

${ }^{5}$ Clinic of Infectology and Travel Medicine, Jessenius Faculty of Medicine Comenius University in Martin;

${ }^{6}$ Department of Orthopaedics, Faculty Hospital in Žilina
\end{abstract}

\begin{abstract}
Summary
Dirofilariosis is a vector-borne disease that is spreading in Europe from the southern endemic regions to the northern countries, including Slovakia. The dog parasites Dirofilaria immitis and D. repens are zoonotic agents, responsible for the development of human pulmonary and subcutaneous dirofilariosis, respectively. The present paper reports the third case of human dirofilariosis in Slovakia caused by D. repens. The pacient, a 41-year-old woman, was referred with tumour process in the subcutaneous area of the right forearm. Within 14 days the USG confirmed the rapid increase of the nodule from $20 \times 10 \mathrm{~mm}$ to $30 \times 25 \mathrm{~mm}$. The surgical extirpation of the tumour was indicated. Histological examination revealed the formation with eosinofilic rime and the presence of a worm in the centre, detected as D. repens.
\end{abstract}

Keywords: human dirofilariosis; Dirofilaria repens; Slovakia

\section{Introduction}

Climatic changes, together with an increase in the movement of dogs and cats across Europe, cause an increase in the geographical range of vector-borne parasites like Dirofilaria, and in the risk of infection for animals and humans (Genchi et al., 2009). In additional to global warming, other important drivers for the emerging and spreading of vector-borne parasite include habitat changes, alterations in water storage and irrigation habits, development of insecticide and drug resistance, globalization and the increase in international trade, tourism and travel (Harrus \& Baneth, 2005). Dirofilariosis is a vector-borne parasitic infection mainly of dogs and cats. In Europe, there are occurred two zoonotic species Dirofilaria immitis and D. repens. The life cycle consists of five larval stages developing both in an intermediate host that also acts as vector and in a definitive vertebrate host. Male and female $D$. immitis adults occur in the pulmonary arteries and right heart chambers and cause heartworm (HW) disease in dogs and cats while D. repens is found mainly in subcutaneous tissues. Adult female Dirofilaria releases embryos (microfilariae) into the blood (Genchi et al., 2009). Usually, the parasites do not develop to adult stages in humans. The intermediate hosts and vectors are nearly 70 species of mosquitoes of the genuses Aedes, Anopheles and Culex. Transmission of dirofilariosis is dependent upon the presence of sufficient number of infected, microfilaraemic dogs, susceptible mosquitoes, and a suitable climate to permit extrinsic incubation of Dirofilaria in the mosquito intermediate host (Medlock et al., 2007).

Human infections by $D$. immitis or $D$. repens are common, but only a part of these is clinically manifested as pulmonary or subcutaneous dirofilariosis. Human dirofilariosis is characterized by nodules that appear when preadult/adult worms are arrested in a pulmonary artery branch $(D$. immitis) or in subcutaneous tissue (D. repens), causing coagulation necrosis and inflammatory cell infiltration (Pampiglione \& Rivasi, 2007). The nodules are benign, but they can be confused with lung or cutaneous cancer. Human cases reported that women are affected by dirofilariosis more often than men, age group distribution shows a higher incidence of cases after 40 years of age in both sexes (Muro et al., 1999). At the last decade the number of human autochthonous dirofilariosis has been diagnosed out of the old endemic Mediterranean countries, in northern and eastern Europe (Kramer et al., 2007; Szénási et al., 2008; Genchi et al., 2009). Slovakia is one of these new areas, where autochthonous canine and human dirofilariosis was confirmed (Svobodová et al., 2005; Miterpáková et al., 2008; Bábal et al., 2008; Ondriska et al., 2010). In this 
work the third case of human dirofilariosis in Slovakia is identified.

\section{Case report}

A 41 - years old woman in Slovak republic visited the hospital because of a formation in the inner site of right elbow that has been observed for one week. History of trauma or injury was negative. Travel history revealed the stay in Canada and Croatia 6 months before appearance of first signs of the disease. Objectively subcutaneous tangible small nodule at the site of right condyle of humerus measuring $20 \times 10 \mathrm{~mm}$, movable against the skin and base was described. The skin over the formation was without pathological findings or inflammation. Punction of the formation was diagnostically not significant. USG examination disclosed a formation over right carpal flexor muscles that measured $32 \times 18 \times 12 \mathrm{~mm}$ and was localized at the medial site of anterocubital area. The hypoechogenic part $(13 \times 18 \mathrm{~mm})$ was identified in the centre of the formation without communication to joint. Because of progressive growth that lasted 3 weeks, the surgical exstirpation of the formation was performed. The surgical conclusion confirmed the USG result. The tissue was sent for histological examination.

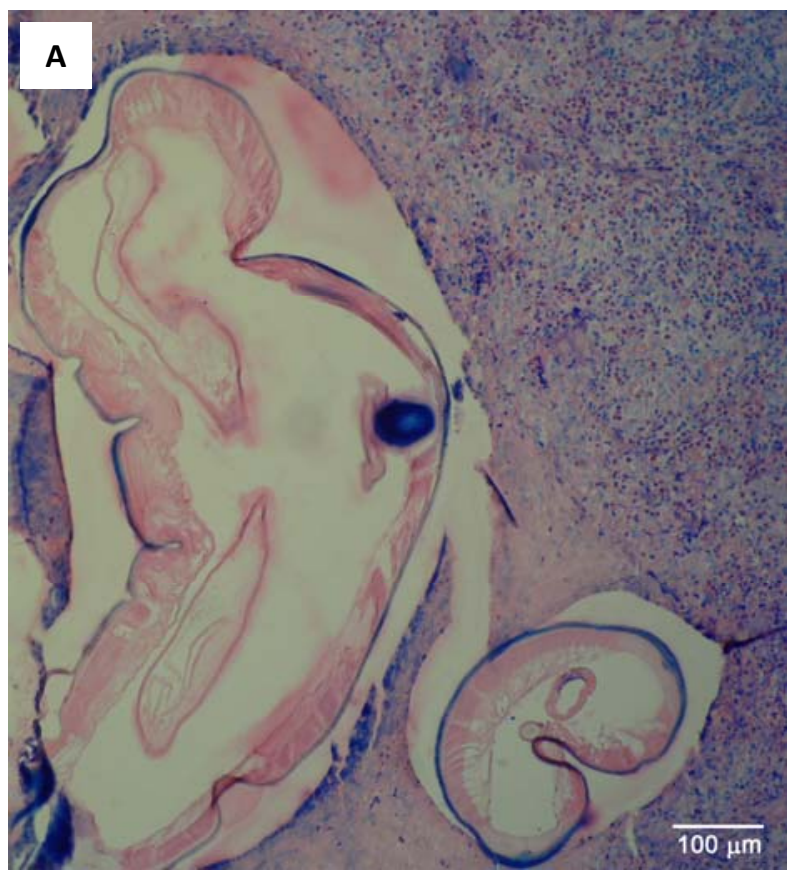

identification by morphological data. Longitudinal and cross sections of unknown organism with cuticle and not stained inner area were observed and eosinophils surrounded the formations. The diameters of the parasites were 330 and $390 \mu \mathrm{m}$ (Fig. 1. A). The external cuticular ridges (ECRs) were noted at the worms. The presence of ECRs is crucial element to differ D. repens from other subgenus Dirofilaria, which own a smooth cuticle. The worms were surrounded by eosinophilic inflammatory infiltration, they were identified as round worms v.s. Dirofilaria sp. The typical iridescence of multilayers cuticle was observed in polarised light, that is typical for D. repens. The multilayered cuticle with external lateral longitudinal ridges, thick hypodermis, and well-developed coelomyarial muscles are diagnostic signs of $D$. repens (hematoxylin and eosin stain) (Fig. 1. B).

\section{Discussion}

Many European countries have become new endemic areas for Dirofilaria infections due to climatic changes and global movement of animals and humans. This work reports the third case of subcutaneous dirofilariosis in Slovakia caused by $D$. repens. The previous two cases came from endemic areas for Dirofilaria spp. in dogs in the

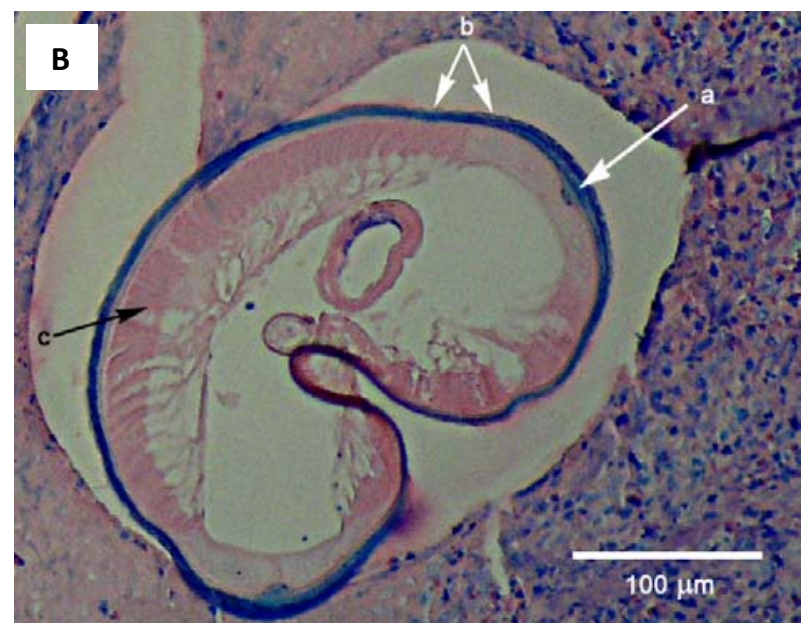

Fig. 1. A - Histological longitudinal and cross sections of worms with eosinophil rime in light microscope, magnification 240x. B - The worm cross section. a - multilayered cuticle, b - external cuticular ridges, c - longitudinal muscles

\section{Histological examination}

The extirped material was fixed in formalin and routinely processed in paraffin. Histological sections of $5 \mu \mathrm{m}$ were stained by hematoxilin-eosin.

\section{Light microscopy}

Histological examination was focused on the parasite southwestern Slovakia (Bábal et al., 2008; Ondriska et al., 2010; Miterpáková et al., 2010). The diagnosis of our patient was based on clinical signs and morphological detection of the parasite. Woman came from the middle Slovakia, confirmed a stay in Croatia and Canada six months ago the nodule appearance, but a source of the infection was not revealed. An important and also autochthonous infection could be considered. 
The detection and diagnosis of human dirofilariosis present two different aspects. In the case of subcutaneous nodules, it is usually the patient who seeks medical attention, while most pulmonary nodules are detected accidentally, by thoracic radiography. Given that both subcutaneous and pulmonary nodules can cause suspicion of a malignant tumour and other pathological conditions, surgery is usually recommended. Histological identification of worms in the nodules may be problematical because of similarities in morphological features between species and also because of the disruption of normal anatomy by the tissue response of the host (MacDougal et al., 1992). As alternatives, serological and molecular biological techniques could be applied. Serological studies carried out in endemic areas showed a high seroprevalence $(21 \%)$ of Dirofilaria antibodies, what indicates that human contact with the parasite is more frequent than the number of reported clinical cases and that most individuals do not develop symptoms (Espinoza et al., 1993).

In the literature, there is trend to relate subcutaneous and ocular dirofilariosis to $D$. repens, while pulmonary disease is usually considered to be caused by $D$. immitis. However, a critical report by Pampiglione et al. (2009) re-evaluated 28 cases of human pulmonary dirofilariosis in Europe attributed to $D$. immitis and corrected diagnoses that pulmonary dirofilariosis in Europe is associated with $D$. repens in contrast to pulmonary infection in the Americas caused by $D$. immitis. They proposed two hypotheses to explain this different pathogenic power of $D$. immitis: i) there are twin populations with different genotypes on two side of the Atlantic ii) the infective capacity to humans of the parasite could be modified in Europe by some factor (inherent to the vector) affecting the vector-parasite relationship decreasing the survival of the larvae. They also suppose that human organism in Europe seems to be unsuitable for the development of $D$. immitis larvae.

In spite of the trend to divide human dirofilariosis in two different clinical manifestations, existing data indicate a higher development capacity of $D$. repens than $D$. immitis in the human host: i) there exist higher incidence of subcutaneous than pulmonary cases, even in areas where $D$. immitis predominates over D. repens in dog population (Simón et al., 2009) ii) D. repens intact live worms are recovered from many subcutaneous nodules (Pampiglione $\&$ Rivasi, 2007) iii) Subcutaneous cases contain both males and females of $D$. repens in the nodules, but $D$. immitis do not (Fernando et al., 2000).

The difference between most human cases diagnosed as $D$. repens infection and a higher prevalence of $D$. immitis in dog populations could be explained by immunological study by Gonzáles-Miguel et al. (2010) who identified immunoreactive proteins of $D$. immitis and D. repens from patient sera. Comparing their results with $D$. immitis canine infection by Olega et al. (2009) it seems that human host presents a greater reactivity than the dog against $D$. immitis, which is consistent with its limited capacity of development in humans when compared to the dogs.

In Slovakia, Miterpáková et al. (2008, 2010) detected highly endemic areas in the Danubian Lowland in southwestern Slovakia and also in Eastern Slovak Lowland, with mean $34.5 \%$ prevalence of dirofilariosis in dogs. Our patient lives out of them, but she often travels not only across Slovakia, but throughout the world. Infected dogs, repeated floods, an increased abundance of mosquitoes represent a high risk of human infection. It would be supposed new cases of human dirofilariosis will appear in new areas of Europe.

\section{Acknowledgement}

The study has been supported by the VEGA Projects No. 2/0134/09 and No. 1/0038/08 and by the Project "INFEKTZOON - Centre of Excellence For Animal Infections and Zoonoses (ITMS-26220120002)" on the basis of support from Operational Programme Research and Development, funded by the European Regional Development Fund (P 0.5).

\section{References}

BÁBAl, P., KobzovÁ, D., NovÁK, I., DubinskÝ, P., JALILI, N. (2008): First case of cutaneous human dirofilariosis in Slovak Republic. Bratisl. Med. J., $109: 486$ - 488

EspinózA, E., Cordero, M., Muro, A., Lorente, F., SIMÓN F. (1993): Anti-Dirofilaria immitis IgE: seroepidemiology and seasonal-variation in an exposed humanpopulation. Trop. Med. Parasitol., 44: $172-176$

Fernando, S. D., Ihalamulla, R. L., De Silva, W. A. (2000): Male and female filarial worms Dirofilaria (Nochtiella) repens recovered from the scrotum. Ceylon Med. J., 45: $131-132$

Genchi, C., Rinaldi, L., Mortarino, M., Genchi, M., CRINGOLI, G. (2009): Climate and Dirofilaria infection in Europe. Vet. Parasitol., 163: 286 - 292

GonzÁlez-Miguel, J., Rosario, L., Rota-NodAri, E., MORCHÓN, R., SiMÓN, F. (2010): Identification of immunoreactive proteins of Dirofilaria immitis and D. repens recognized by sera from patients with pulmonary and subcutaneous dirofilariosis. Parasitol. Int., 59: 248 - 256

HARRUS, S., BANETH, G. (2005): Drivers for the emergence and re-emergence of vector-borne protozoal and bacterial diseases. Int. J. Parasitol., 35: 1309 - 1318

Kramer, L. H., KartasheV, V. V., Grandi, G., Morchon, R., NAgornit, S. A., Karanis, P., SimÓn, F. (2007): Human subcutaneous dirofilariasis, Russia. Emerg. Infect. Dis., 13: 150 - 152

MacDougal, L. T., Magoon, C. C., Fritsche, T. R. (1992): Dirofilaria repens manifesting as a breast nodule diagnostic problems and epidemiologic considerations. Am. J. Clin. Pathol., 97: 625 - 630

Medlock, J. M., Barrass, I., Kerrod, E., Taylor, M. A., LEACH, S. (2007): Analysis of climatic predictions for extrinsic incubation of Dirofilaria in the United Kingdom. Vector-Borne Zoonot., 7: 4 - 14

Miterpáková, M., Antolová, D., Hurníková, Z., DUBINSKÝ, P. (2008): Dirofilariosis in Slovakia - a new ende- 
mic area in Central Europe. Helminthologia, 45: 20 - 23 MiterpákovÁ, M., Antolová, D., HurníkovÁ, Z., DUBinskÝ, P., PAVlaČKA, A., NÉMETH, J. (2010): Dirofilaria infections in working dogs in Slovakia. $J$. Helminthol., 84: 173 - 176

Muro, A., Genchi, C., Cordero, M., Simón, F. (1999): Human dirofilariasis in the European union. Parasitol. Today, 15: $386-389$

Oleaga, A., Peréz-Sanchéz, R., Pages, E., MarcosATXUTEGI, C., SiMÓN, F. (2009): Identification of immunoreactive proteins from the dog heartworm (Dirofilaria immitis) differentially recognized by the sera from dogs with patent or occult infections. Mol. Biochem. Parasit., 166: $134-141$

ONDRISKA, F., LENGYEL, D., MiterPÁKOVÁ, M., Lengyelová, B., StrehÁrovÁ, A., DubinskÝ, P. (2010): Human dirofilariosis in the Slovak republic - a case report. Ann. Agr. Env. Med., 17: $169-171$

PAMPIGLIONE, S., RIVASI, F. (2007): Human dirofilariasis due to Dirofilaria (Nochtiella) repens: an update of world literature from 1995 to 2000. In GENCHI, C., RONALDI, L., CRINGoli, G., (Eds.): Dirofilaria immitis and D. repens in dog and cat and human infections. Italia Rolando Editore; 2007, pp. $81-116$

Pampiglione, S., Rivasi, F., Gustinelli, A. (2009): Dirofilarial human cases in the Old World, attributed to Dirofilaria immitis: a critical analysis. Histopathology, 54: 192 $-204$

SimÓn, F., MORChON, R., GONZÁleZ-Miguel, J., Marcos-AtXutegi, C., Siles-Lucas, M. (2009): What is new about animal and human dirofilariosis? Trends Parasitol., 25: $404-409$

Svobodová, V., Svobodová, Z., Beladičová, V., VALENTOVÁ, D. (2005): First cases of canine dirofilariosis in Slovakia: a case report. Vet. Med. - Czech., 50: 510-512 SzÉnÁsi, Z., KovÁcs, A. H., PAMPiglione, S., Fioravanti, M. L., KuCSERA, I., TÁnczos, B., TISZlAVICZ, L. (2008): Human dirofilariosis in Hungary: an emerging zoonosis in central Europe. Wien. Klin. Wochenschr., 120: 96 - 102 